\title{
PERANCANGAN SISTEM INFORMASI AKUNTANSI PENJUALAN KREDIT PADA PT. BAYU INTI MEGAH ABADI
}

\author{
Ashri Nuraini ${ }^{1}$, Suwandi ${ }^{2}$, Amroni $^{3}$ \\ Universitas Catur Insan Cendekia \\ Jl. Kesambi No. 202, Cirebon \\ e-mail: ashrinuraini7@gmail.com ${ }^{1}$, suwandi@cic.ac.id², amroniapcic@gmail.com ${ }^{3}$
}

\begin{abstract}
ABSTRAK
PT. Bayu Inti Megah Abadi adalah perusahaan dagang yang mendistribusikan Semen Bima di wilayah Ciayumajakuning (Cirebon, Indramayu, Majalengka, Kuningan) dan Kabupaten Subang. Transaksi penjualan yang dilakukan oleh PT. Bayu Inti Megah Abadi belum menggunakan metode pencatatan akuntansi pada transaksi penjualan kreditnya. Tujuan dari penelitian ini antara lain untuk mengetahui prosedur-prosedur penjualan kredit pada PT. Bayu Inti Megah Abadi, mengetahui apa saja dokumen dan catatan yang digunakan dalam prosedur penjualan kredit pada PT. Bayu Inti Megah Abadi, mengetahui metode pencatatan akuntansi yang digunakan pada PT. Bayu Inti Megah Abadi. Metode pencatatan akuntansi yang digunakan adalah Metode Accrual Basis. Hasil dari penelitian ini adalah sebuah aplikasi program khusus berupa Aplikasi Penjualan Kredit Dengan Metode Accrual Basis yang telah menerapkan prosedur-prosedur terkait pencatatan penjualan kredit pada PT. Bayu Inti Megah Abadi dapat berjalan dengan baik, selain itu aplikasi yang dibuat dapat menghasilkan dokumen dan catatan yang digunakan dan dapat memudahkan manajemen dalam membuat keputusan.
\end{abstract}

Kata Kunci: Perancangan, Sistem Informasi Akuntansi, Penjualan Kredit, Accrual Basis

\begin{abstract}
PT. Bayu Inti Megah Abadi is a trading company that distributes Semen Bima in the Ciayumajakuning area (Cirebon, Indramayu, Majalengka, Kuningan) and Subang Regency. Sales transactions made by PT. Bayu Inti Megah Abadi has not used the accounting method of recording his credit sales transactions. The purpose of this study, among others, to determine the procedures for credit sales at PT. Bayu Inti Megah Abadi, knows what documents and records are used in the credit sales procedure at PT. Bayu Inti Megah Abadi, knows the accounting recording method used at PT. Bayu Inti Megah Abadi. The accounting recording method used is the Accrual Basis Method. The result of this research is a special application program in the form of a Credit Sales Application with the Accrual Basis Method which has implemented procedures related to the recording of credit sales at PT. Bayu Inti Megah Abadi can run well, besides that the application created can produce documents and notes that are used and can facilitate management in making decisions.
\end{abstract}

Keywords: Design, Accounting Information Systems, Credit Sales, Accrual Basis

\section{Pendahuluan}

PT. Bayu Inti Megah Abadi adalah perusahaan dagang yang mendistribusikan Semen Bima di Wilayah Ciayumajakuning (Cirebon, Indramayu, Majalengka, Kuningan) dan Kabupaten Subang. Perusahaan yang bergerak di bidang perdagangan pada umumnya selalu berusaha untuk meningkatkan volume penjualan. Dengan meningkatnya penjualan akan meningkat pula pendapatan perusahaan. Secara umum pernjualan dapat dilaksanakan secara tunai maupun kredit.

Penjualan kredit dilakukan perusahaan dengan cara mengirimkan barang sesuai dengan order yang diterima dari pembeli dan untuk jangka waktu tertentu perusahaan mempunyai tagihan kepada pembeli tersebut. Untuk menghindari tidak tertagihnya piutang, setiap penjualan kredit yang pertama kepada seorang pembeli selalu didahului dengan analisis terhadap calon pembeli. 
Prosedur yang dilakukan di PT. Bayu Inti Megah Abadi meliputi prosedur pemesanan barang, persetujuan kredit, pengiriman barang, penagihan, pencatatan akuntansi dengan melibatkan bagian akuntansi atas fungsi yang terkait dan dokumen-dokumen yang digunakan. Untuk menghindari kecurangan yang terjadi dalam penjualan kredit di PT. Bayu Inti Megah Abadi dilakukan pemisahan fungsi dan dokmen yang bernomor urut tercetak. Sebagai pengawasan atas dokumen yang telah diotorisasi oleh bagian yang berwenang atas informasi yang ada di dalamnya telah disetujui dan dipertanggung jawabkan.

Saat ini PT. Bayu Inti Megah Abadi belum menggunakan metode pencatatan akuntansi atas transaksi penjualan kredit. Untuk itu perlu dibuat pencatatan menggunakan metode karena metode ini bisa digunakan untuk pengukuran aset, kewajiban dan ekuitas. Informasi mengenai penjualan kredit akan lebih terpercaya karena beban dan pendapatan diakui pada saat terjadinya transaksi.

Oleh karena itu penerapan aplikasi penjualan kredit yang dilakukan perusahaan seperti uraian di atas, terdapat faktor-faktor yang melatarbelakangi penulis untuk membuat perancangan sistem informasi akuntansi dengan judul "Perancangan Sistem Informasi Akuntansi Penjualan Kredit Pada PT. Bayu Inti Megah Abadi”.

\section{KAJIAN PUSTAKA}

\subsection{Sistem Informasi Akuntansi}

Sistem informasi akuntansi menurut Mas'ut, Abdan Masrura (2018) adalah sebuah sistem informasi yang menangani segala sesuatu yang berkenaan dengan akuntansi. Berdasarkan definisi di atas Sistem Informasi Akuntansi adalah sekumpulan sub sistem yang saling berkaitan satu sama lain yang menyediakan informasi berfungsi untuk mengelola seluruh aktivitas perusahaan yang diperlukan untuk pengambilan keputusan manajemen dan pimpinan perusahaan dan dapat memudahkan pengelolaan perusahaan.

\subsection{Penjualan Kredit}

Menurut Elok Maharani (2016) penjualan kredit adalah penjualan yang dilakukan dengan perjanjian bahwa pembayaran dilakukan secara bertahap, yaitu pada saat barang pesanan telah dikirimkan ke pembeli, penjual menerima pembayaran pertama sebagian dari harga total penjualan dan sisanya akan dibayar sesuai dengan kesepakatan bersama.

Menurut L.H Tumalun (2019) penjualan kredit adalah penjualan dengan metode pembayaran berangsur. Dengan membayar uang muka da uang setoran bulanan pembeli dapat membawa pulang barang/jasa yang dibeli. Setiap pengajuan pembelian kredit ada syarat-syarat yang diberikan oleh pihak perusahaan. Ketika proses penjualan kredit terjadi akan timbul piutang, yaitu perusahaan akan menagih uang tagihan sesuai waktu dan nominal disepakati.

Jadi dapat disimpulkan bahwa penjualan kredit yaitu proses penjualan barang dimana pembayaan atas transaksi tersebut ditangguhkan dan akan dibayar pada batas waktu tertentu dengan atau syarat sehingga menjadi piutang bagi perusahaan.

Prosedur penjualan pada suatu perusahaan baik penjualan tunai maupun kredit dapat dikatakan baik apabila melakukan transaksi dari awal hingga akhir tidak dilakukan oleh satu bagian saja melainkan oleh lebih dari satu bagian yang sesuai dengan fungsinya masing-masing. Hal ini guna menghindari kecurangan-kecurangan yang mungkin akan terjadi.

\subsection{Metode Pengakuan Pendapatan}

Masalah waktu yang tepat untuk mengakui pendapatan telah menjadi perhatian besar selama beberapa tahun terakhir. Oleh karena itu secara konseptual pendapatan hanya diakui jika memenuhi kualitas keterukuran dan keterandalan. Menurut Yuri Rahayu (2015) dasar pengakuan pendapatan secara umum ada dua cara yaitu :

\subsubsection{Basis Kas (Cash Basis)}

Pengakuan pendapatan pada cash basis adalah pada saat perusahaan menerima pembayaran secara kas. Dalam konsep cash basis menjadi hal yang kurang penting mengenai hak untuk menagih. Pencatatan pada saat pendapatan dan kas diterima : 
Tabel 1. Pencatatan Pendapatan dan Kas Diterima

\begin{tabular}{|l|l|l|l|l|}
\hline Tanggal & Keterangan & Ref & Debit & Kredit \\
\hline $\mathrm{Xx}$ & Kas & & $\mathrm{Xxx}$ & \\
& Penjualan/Pendapatan & & & $\mathrm{Xxx}$ \\
\hline
\end{tabular}

\subsubsection{Basis Akrual (Accrual Basis)}

Pada dasar akrual ini, pendapatan diakui saat diperoleh dan saat direalisasi dan terjadi ketika perusahaan menyerahkan produk atau jasanya. Pendapatan dapat direalisasi saat memperoleh aktiva yang dapat diubah menjadi kas atau setara kas serta dapat diakui saat barang atau jasa masih dalam produksi, selesai diproduksi atau tergantung keadaan suatu perusahaan. Jadi dalam transaksi penjualan barang dan jasa yang dilakukan walaupun kas belum diterima, maka transaksi tersebut sudah dicatat dan diakui sebagai pendapatan perusahaan. Pencataan pada saat pengakuan pendapatan :

Tabel 2. Pencatatan dalam Pendapatan

\begin{tabular}{|l|l|l|l|l|}
\hline Tanggal & Keterangan & Ref & Debit & Kredit \\
\hline $\mathrm{Xx}$ & $\begin{array}{c}\text { Piutang } \\
\text { Penjualan/Pendapatan }\end{array}$ & & $\mathrm{Xxx}$ & \\
& & & $\mathrm{Xxx}$ \\
\hline
\end{tabular}

Tabel 3. Pencatatan Kas Diterima

\begin{tabular}{|l|l|l|l|l|}
\hline Tanggal & Keterangan & Ref & Debit & Kredit \\
\hline $\mathrm{Xx}$ & Kas & & $\mathrm{Xxx}$ & \\
& \multicolumn{1}{|c|}{ Piutang } & & & $\mathrm{Xxx}$ \\
\hline
\end{tabular}

\section{METODE PENELITIAN}

\section{B.1. Metode}

Metode yang penulis gunakan dalam pembuatan Tugas Akhir ini adalah metode Waterfall. Metode Waterfall ini memungkinkan dapat mengontrol, meminimalisir kesalahan pengerjaan sistem. Proses pengembangan metode Waterfall ini sistematis dan berurutan dalam membangun sistem. Sistem yang dihasilkan akan berkualitas baik, dikarenakan pelaksanaannya secara bertahap sehingga tidak terfokus pada tahap tertentu. Tahapan dari metode Waterfall adalah:

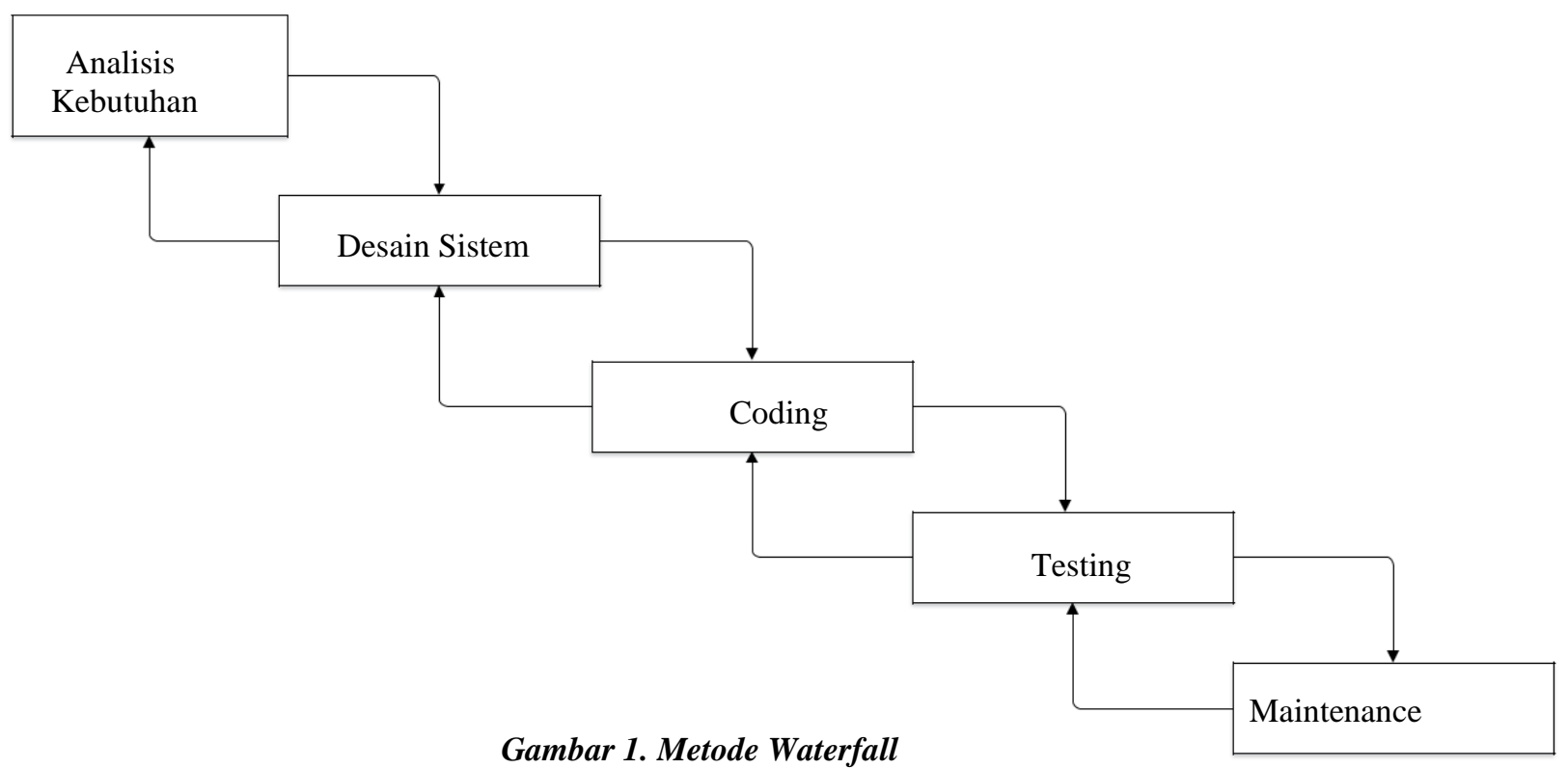




\subsection{Flowchart}

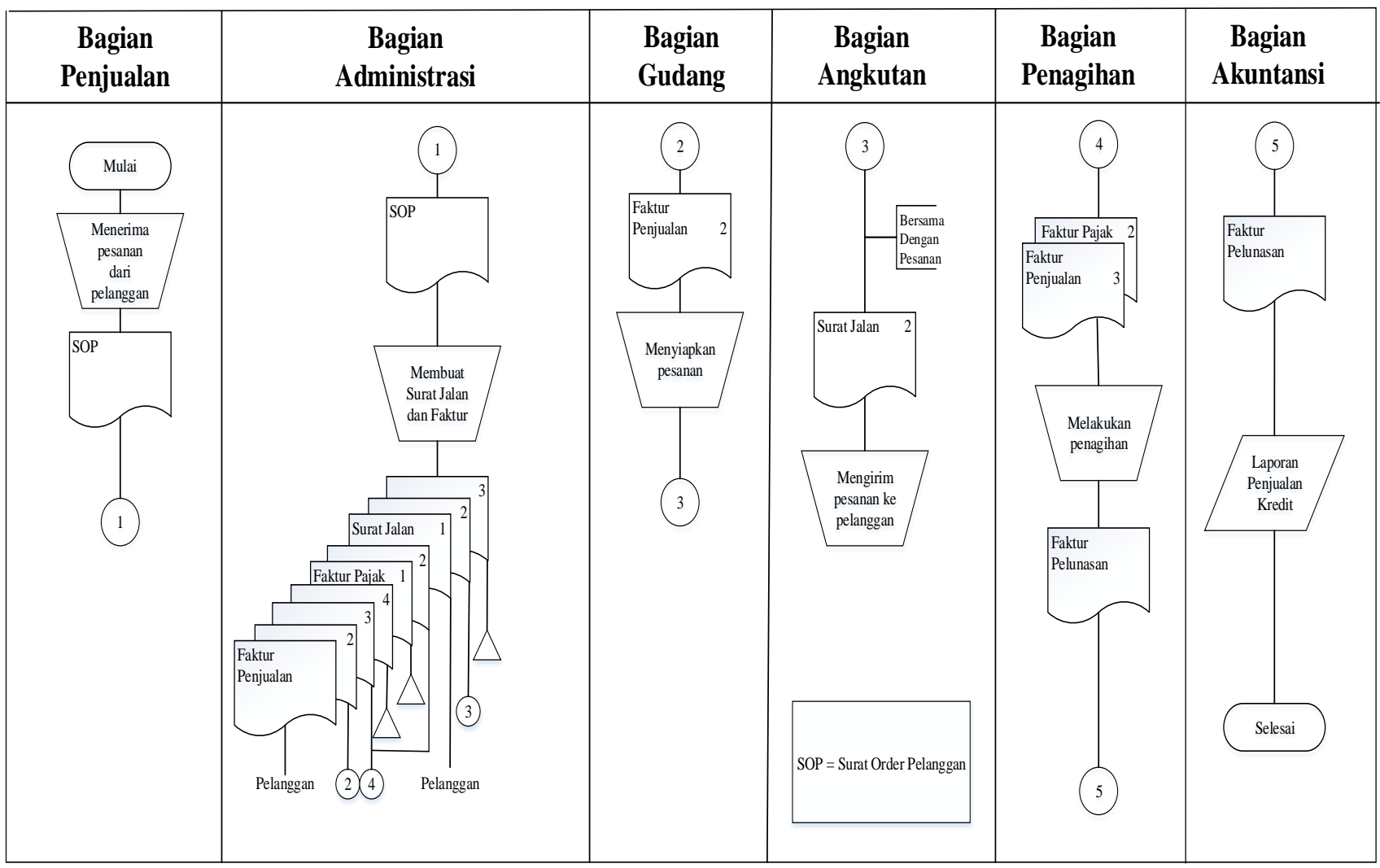

Gambar 2. Flowchart

\section{Keterangan:}

1. Bagian penjualan menerima pesanan dari pelanggan kemudian pesanan tersebut dikirim ke bagian administrasi.

2. Bagian administrasi menerima pesanan dari bagian penjualan kemudian bagian ini membuat surat jalan, faktur penjualan dan faktur pajak.

3. Bagian gudang menerima faktur penjualan dari bagian administrasi, setelah itu bagian ini menyiapkan pesanan kemudian pesanan tersebut dikirim ke bagian angkutan.

4. Bagian angkutan menerima surat jalan dari bagian administrasi dan menerima pesanan dari bagian gudang. Lalu bagian angkutan mengirim persanan tersebut ke pelanggan.

5. Bagian penagihan menerima faktur penjualan dan faktur pajak dari bagian administrasi kemudian kedua faktur tersebut digunakan sebagai bukti kepada pelanggan untuk melunasi tagihannya. Lalu faktur penjualan dan faktur pajak yang sudah dilunasi dikirim ke bagian akuntansi.

6. Bagian akuntansi menerima faktur penjualan dan faktur pajak dari bagian penagihan, kemudian datadata tersebut dimasukan kedalam laporan penjualan kredit. 


\subsection{Flowmap}

Flowmap menurut M Haidar Bagir, Bramantiyo Eko Putro (2018) adalah campuran peta dan flowchart yang menunjukkan pergerakan benda dari satu lokasi ke lokasi lain. Seperti jumlah orang migrasi, jumlah barang yang diperdagangkan atau jumlah paket dalam jaringan. Flowmap menolong analis dan programmer untuk memecahkan masalah ke dalam segmen atau bagian yang lebih kecil dan menolong dalam menganalisis alternatif-alternatif dalam pengoperasian.

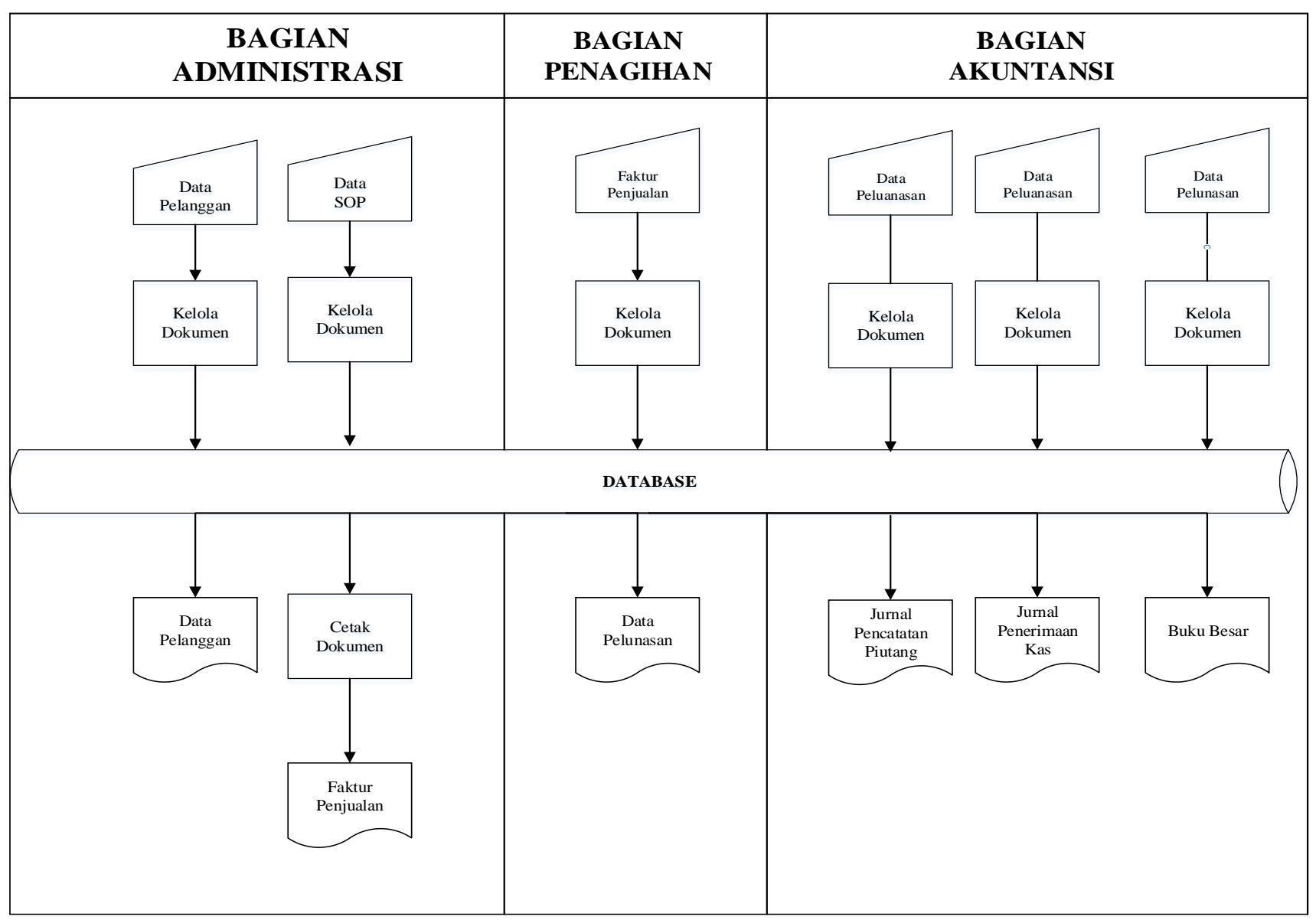

Gambar 3. Flowmap Komputerisasi

\section{Keterangan:}

1. Bagian administrasi menginput data pelanggan kemudian mengelola dokumen dan menghasilkan data pelanggan.

2. Bagian administrasi menginput data SOP kemudian mengelola dokumen dan mecetak faktur penjualan.

3. Bagian penagihan menampilkan faktur penjualan kemudian mengelola dokumen dan mencetak data pelunasan.

4. Bagian akuntansi menampilkan data pelunasan kemudian mengelola data tersebut dan menghasilkan jurnal pencatatan piutang.

5. Bagian akuntansi menampilkan data pelunasan kemudian mengelola data tersebut dan menghasilkan jurnal penerimaan kas.

6. Bagian akuntansi menampilkan data pelunasan kemudian mengelola data tersebut dan menghasilkan buku besar. 


\subsection{Diagram Konteks}

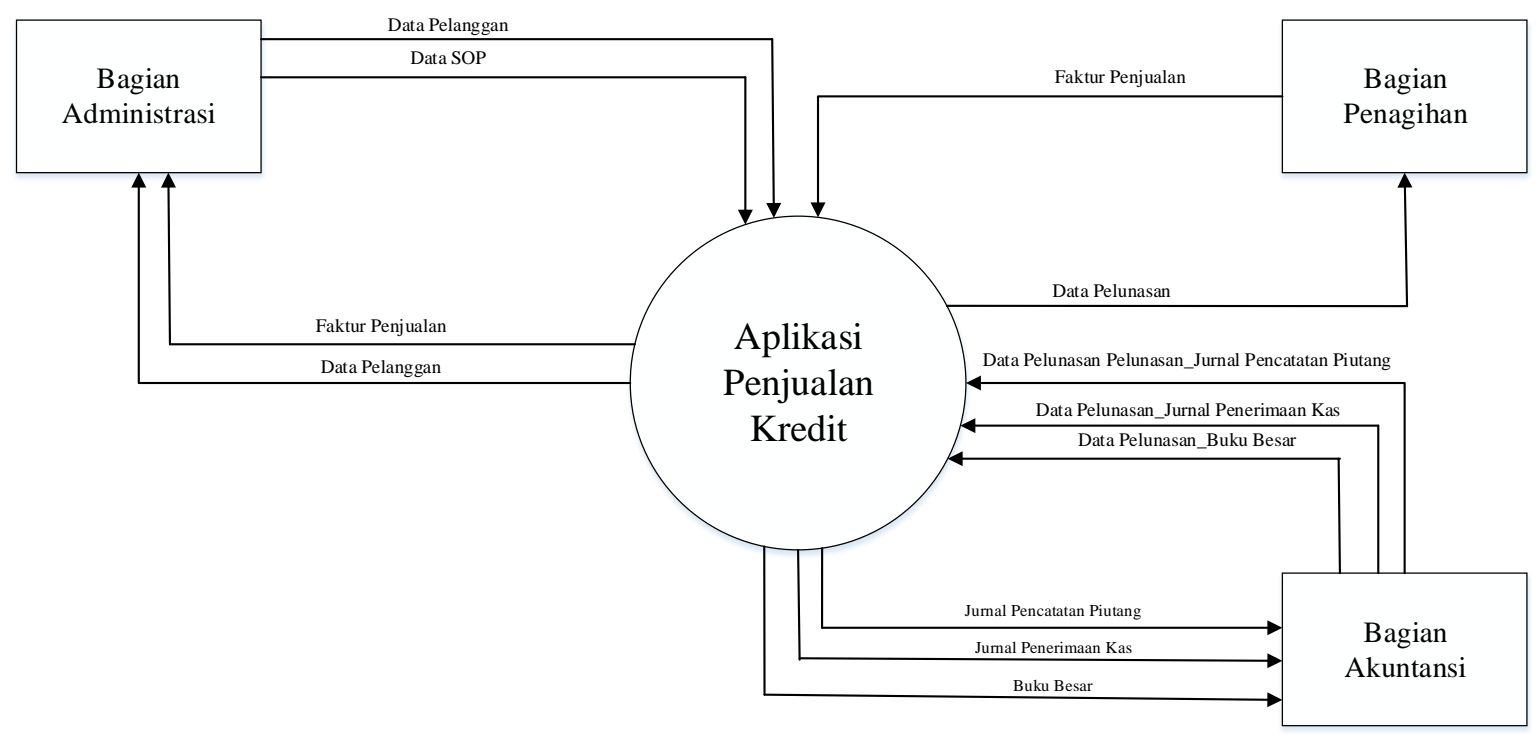

Gambar 4. Diagram Konteks

\subsection{Diagram Hubungan Antar Entitas (Entity Relationship Diagram/ERD)}

Pada Entity Relationship Diagram (ERD), diberikan gambaran dari aktivitas entitas pada sebuah aplikasi, setiap entitas yang ada akan digambarkan bersama dengan atribut-atributnya. Berikut merupakan Entity Relationship Diagram (ERD) Penjualan Kredit pada PT. Bayu Inti Megah Abadi:

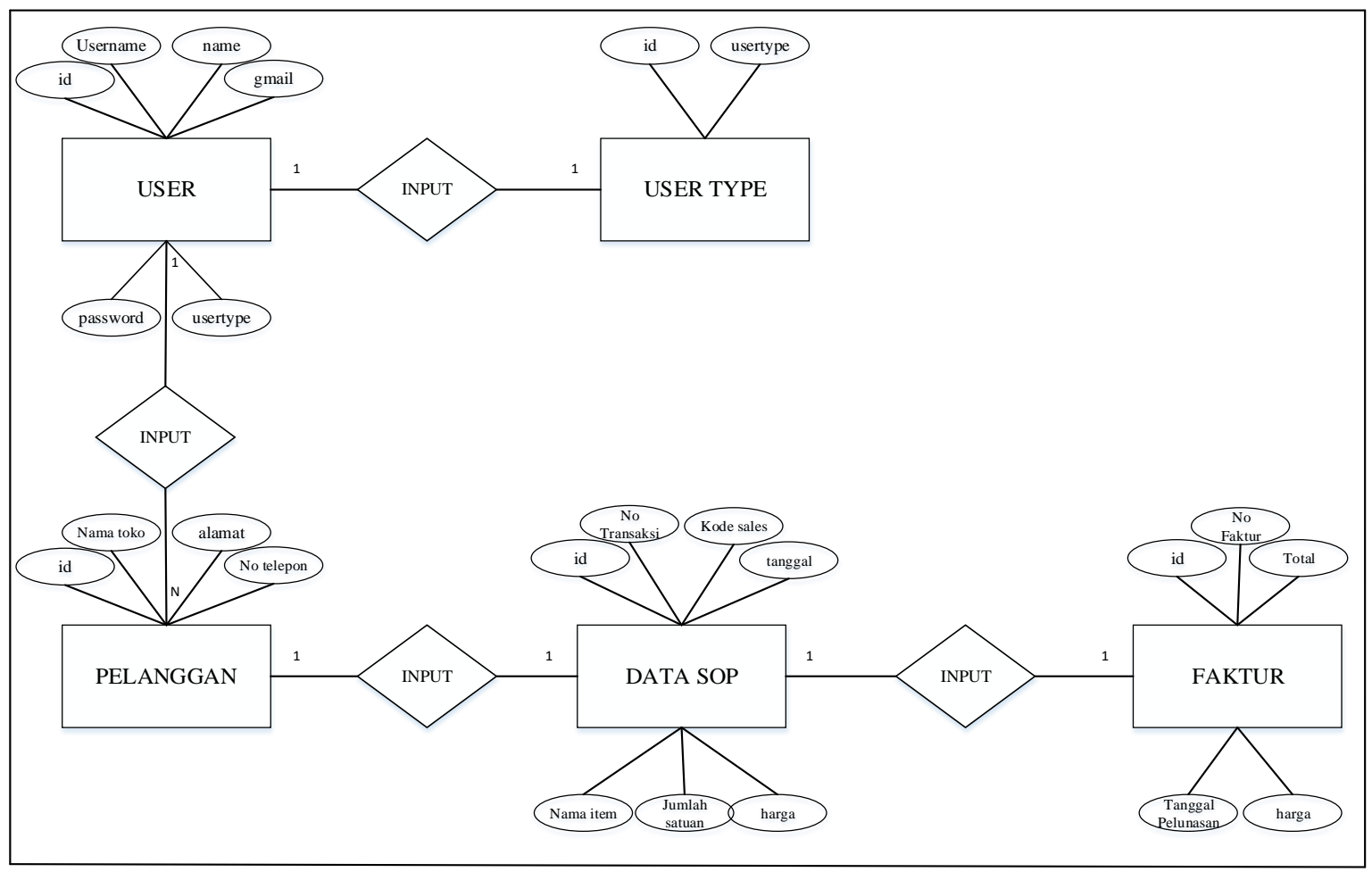

Gambar 5. Entity Relationship Diagram

Perancangan Sistem Informasi Akuntansi Penjualan Kredit Pada PT. Bayu Inti Megah Abadi (Ashri Nuraini, Suwandi, Amroni) 


\section{HASIL DAN PEMBAHASAN}

\subsection{Form Login Semua Bagian}

\section{BBima}

PT BAYU INTI MEGAH ABADI

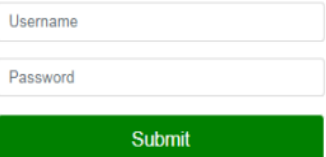

Gambar 6. Form Log In

Form login merupakan form yang digunakan oleh user untuk dapat masuk kedalam aplikasi sesuai dengan hak aksesnya. Form ini terdiri dari Username, Password dan tombol Submit. Berikut ini penjelasannya:

1. Username merupakan nama perngguna aplikasi yang sudah terdaftar dalam tabel user.

2. Password merupakan kata sandi dari username agar dapat masuk ke dalam aplikasi.

3. Submit merupakan tombol untuk masuk kedalam aplikasi yang digunakan oleh user ketika login menampilkan menu utama, tetapi username dan password harus diisi sesuai dengan yang sudah terdaftar didalam tabel.

\subsection{Form Menu Utama Bagian Administrasi}

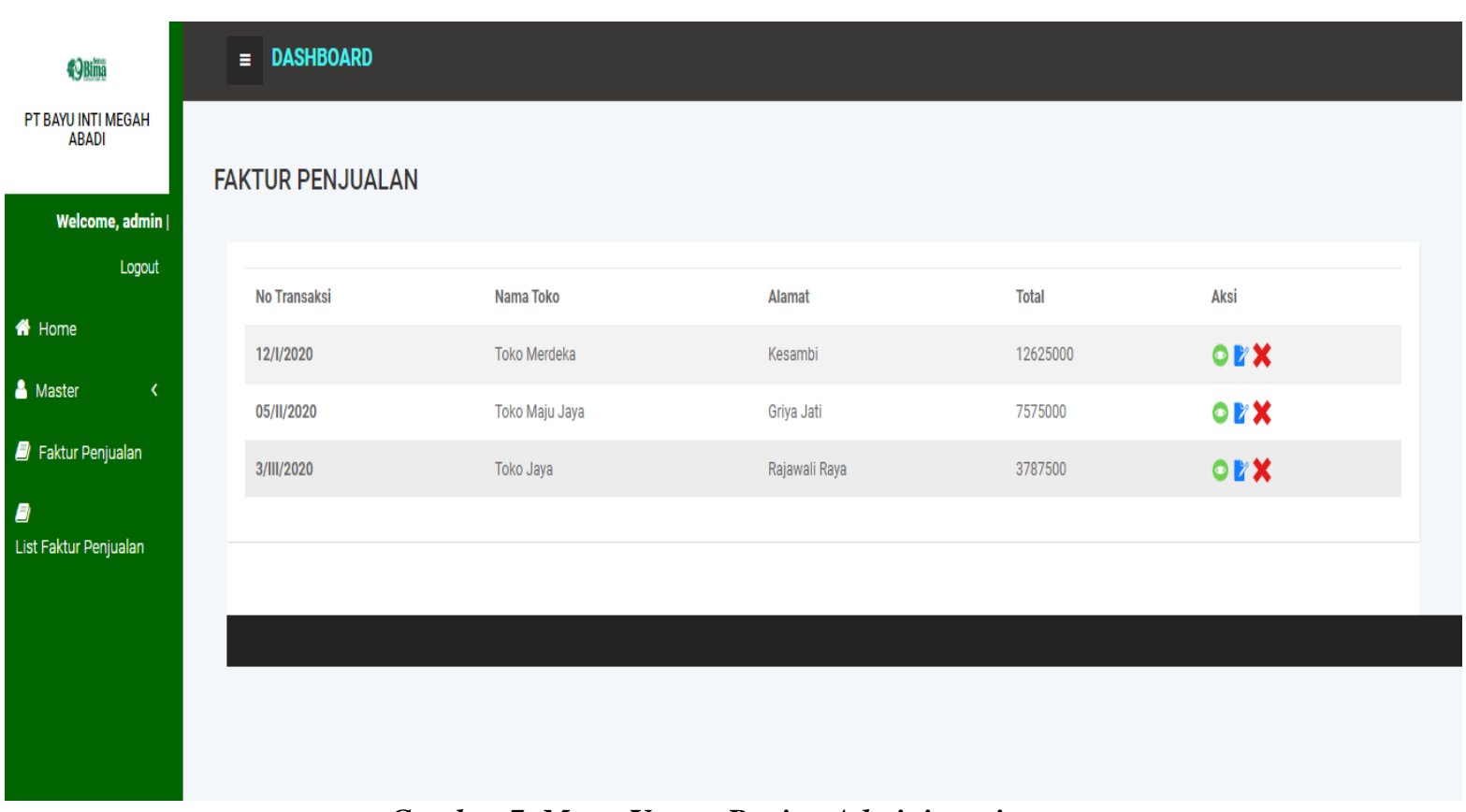

Gambar 7. Menu Utama Bagian Administrasi 
Form menu utama menampillkan menu-menu yang terdapat dalam aplikasi pada semua bagian. Berikut ini adalah menu-menu yang terdapat dalam aplikasi:

1. Menu Home merupakan menu untuk menampilkan halaman awal aplikasi. Pada aplikasi ini terdapat data faktur penjualan.

2. Menu Master Data Pelanggan merupakan menu untuk menampilkan dan menginput data pelanggan baru.

3. Menu Faktur Penjualan merupakan menu untuk menginput data faktur penjualan.

4. Menu List Faktur Penjualan merupakan menu untuk menampilkan faktur penjualan yang sudah diinput.

5. Tombol View di kolom aksi untuk menampilkan faktur penjualan.

6. Simbol Edit di Kolom Aksi, digunakan untuk mengubah atau mengedit faktur penjualan yang akan di update di tabel data sop.

7. Simbol Hapus di Kolom Aksi, digunakan untuk menghapus data faktur penjualan dari tabel data sop.

8. Tombol cetak untuk mencetak.

\subsection{Form Menu Jurnal Pencatatan Piutang}

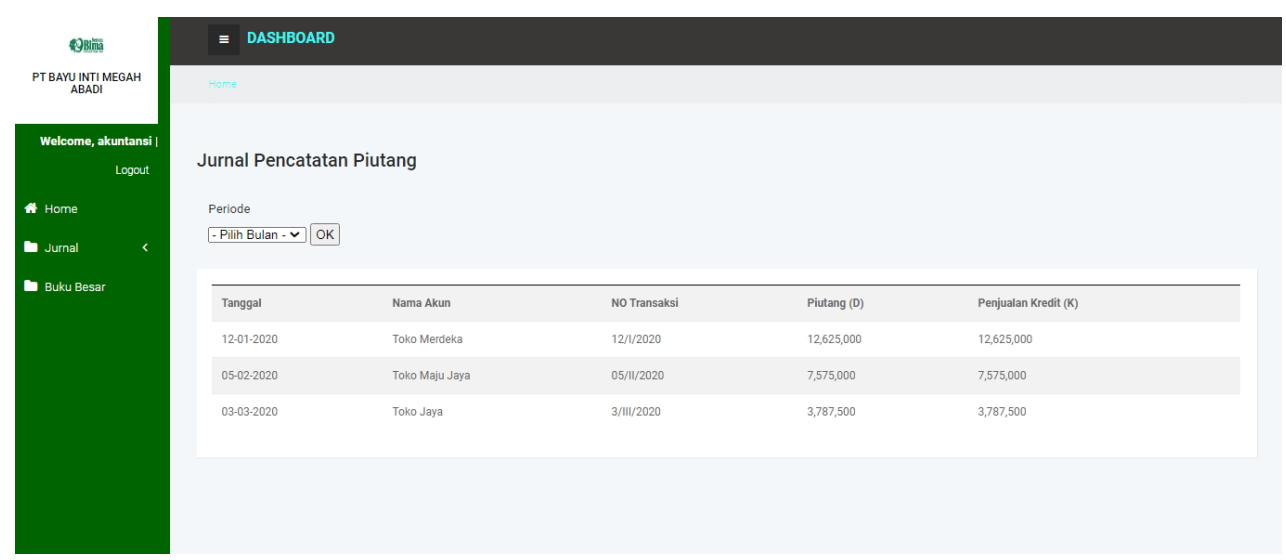

Gambar 8. Jurnal Pencatatan Piutang

\subsection{Faktur Penjualan}

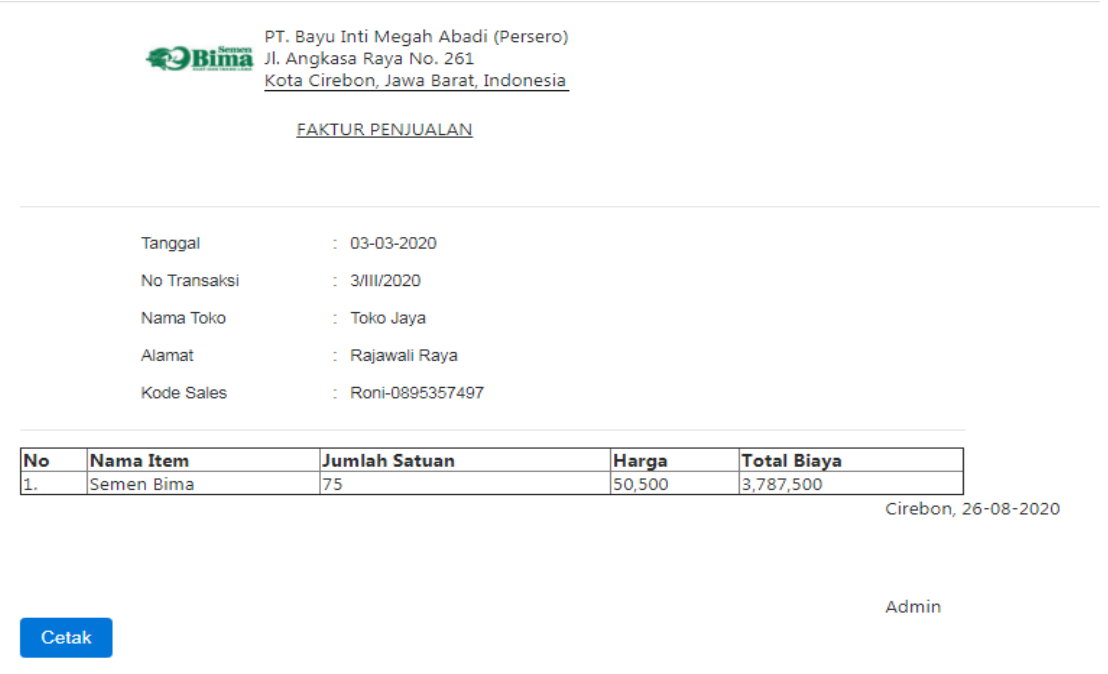

Gambar 9. Faktur Penjualan

Perancangan Sistem Informasi Akuntansi Penjualan Kredit Pada PT. Bayu Inti Megah Abadi (Ashri Nuraini, Suwandi, Amroni) 


\section{KESIMPULAN DAN SARAN}

\subsection{Kesimpulan}

Berdasarkan hasil analisa yang telah dilakukan pada studi kasus tentang Aplikasi Penjualan Kredit

Dengan Metode Accrual Basis Pada PT. Bayu Inti Megah Abadi, maka dari itu saya menarik beberapa kesimpulan dari data yang telah dibuat sebagai berikut:

1. Dengan dibuatnya aplikasi ini, prosedur-prosedur terkait pencatatan penjualan kredit pada PT. Bayu Inti Megah Abadi dapat berjalan dengan baik.

2. Aplikasi ini dapat membuat dokumen dan catatan yang digunakan terkait penjualan kredit pada PT. Bayu Inti Megah Abadi.

3. Aplikasi Penjualan Kredit Dengan Metode Pada PT. Bayu Inti Megah Abadi yang dibuat dapat memudahkan manajemen dalam hal pengambilan keputusan.

\subsection{Saran}

Adapun saran yang penulis berikan untuk pengembangan aplikasi ini, sehingga nantinya terjadi keterbaruan dalam aplikasi ini, sebagai berikut:

1. Pengembangan ke depannya aplikasi ini diharapkan dapat membuat pegelolaan pajak penjualan serta laporan pajak penjualan.

2. Diharapkan dalam pengembangannya aplikasi ini dapat menggunakan metode pencatatan akuntansi yang lainnya seperti metode cash basis.

3. Dalam pengembangannya program ini diharapkan dapat menampilkan grafik penjualan setiap bulannya.

\section{DAFTAR PUSTAKA}

[1] Fathansyah. 2015. Basis Data. Bandung: Informatika Bandung.

[2] Hidayatullah, Priyanto dan Kawistara, Jauhari Khairul. 2017. Pemograman Web Edisi Revisi (2017). Bandung: Informatika.

[3] Indah Ramadani, Fitria. 2016. Analisis Penerapan Sistem Sistem Penjualan Kredit Pada PT. Unity Samarinda. Universitas Mulawarman : Jurnal Ilmu Administrasi Bisnis. Volume. 4, No. 3, ISSN : $2355-$ 2408

[4] Juansyah, Andi. 2015. Pembangunan Aplikasi Child Tracker Berbasis Assisted-Global Positioning System (A-GPS) Dengan Platform Android. Universitas Komputer Indonesia : Jurnal Ilmiah Komputer dan Informatika (KOMPUTA) Edisi. 1 Volume. 1, ISSN : 2089-9033

[5] L.H Tumalun, Tommy dan Pangerapan, Sonny. 2019. Analisis Sistem Informasi Akuntansi Penjualan Kredit Di PT. Nusantara Sakti Cabang Manado. Universitas Sam Ratulangi. Volume. 7, No.3, ISSN : 2303-1174

[6] Maharani, Elok. Kertahadi dan Saifi, Muhammad. 2016. Analisis Penerapan Sistem Akuntansi Penjualan Kredit Dan Penerimaan Kas Dalam Mendukung Pengendalian Intern. Universitas Brawijaya : Jurnal Administrasi Bisnis (JAB). Volume. 31, No. 1

[7] Mulyadi. 2016. Sistem Akuntansi Edisi 4. Jakarta: Salemba Empat.

[8] Asfi, M., Suwandi, Setiadi, P. H. (2019), Sistem Informasi Akuntansi Pendapatan Dengan Metode Posting Langsung, Accounting and Management Journal, Universitas Nahdlatul Ulama Surabaya, Vol.3 No. 2 Tahun 2019. ISSN : 2579-9609

[9] Nugraha, Agus Ramdhani dan Pamungkas, Gati. 2017. Sistem Akuntansi Akademik Sekolah Berbasis Web Di Sekolah Menengah Pertama 11 Tasikmalaya. STMIK DCI : Jurnal Manajemen Informatika (JUMIKA) Volume. 4, No. 2, ISN : 2451-6375

[10] Rahayu, Yuri. 2015. Reformasi Sistem Akuntansi Cash Basis Menuju Sistem Akuntansi Accrual Basis. AMIK BSI Sukabumi : Jurnal Ecodemica. Volume. 3, No. 1, ISN : 2355-0295 